\title{
PERBANDINGAN PENERBITAN DAN HARGA BUKU MENGIKUT GENRE DI MALAYSIA DAN JEPUN MENGGUNAKAN DATA AKSES TERBUKA DAN SIMULASI MONTE CARLO
}

\author{
COMPARISON OF BOOK PUBLISHED AND AVERAGE PRICE \\ ACCORDING TO BOOK GENRE IN MALAYSIA AND JAPAN USING \\ OPEN ACCESS DATA AND MONTE CARLO SIMULATION METHOD
}

\section{Hadi Akbar Dahlan}

Department of Biotechnology, Graduate School of Engineering, Osaka University, Osaka, JAPAN

Email: hadiakbar1591@rocketmail.com

Published online: 29 October 2021

To cite this article: Hadi Akbar Dahlan. 2021. Perbandingan penerbitan dan harga buku mengikut genre di Malaysia dan Jepun menggunakan data akses terbuka dan simulasi Monte Carlo. Kajian Malaysia 39(2): 179-202. https://doi.org/10.21315/km2021.39.2.8

To link to this article: https://doi.org/10.21315/ km2021.39.2.8

\begin{abstract}
Reading habits are often associated with an increased cognitive level. However, book genre can also affect the cognitive level. This is because different book genres can be attributed to different types of knowledge and tendency towards a specific book genre can be viewed as a preference towards a specific type of knowledge. Research on Malaysians' interest and the tendency towards book genre and type of knowledge can be investigated using the publication data of each book genre and its prices. The objective of this research is to analyse and compare the book publications and the average price of each book's genre in Malaysia with those of Japan. Comparison was done based on book categorisation genre strategy to 12 book genres. Based on Monte Carlo simulation method data, Malaysians are attracted to book genres on language, literature and science. While the Japanese are more interested in the book genres of social sciences and hobbies/art. The similarity between Malaysian and Japanese societies are that both societies also favour book genre of literature. However, it is possible that the themes of literary genre in Japan and Malaysia are very different. The result of this study can be used to identify the differences between Malaysian and Japanese reading habits as
\end{abstract}


well as for formulating strategies to change Malaysian reading habits towards the style of Japanese reading habits.

Keywords: Malaysia, reading interest, book price, genre, Monte Carlo simulation method

\begin{abstract}
ABSTRAK
Amalan pembacaan buku sering dikaitkan dengan peningkatan tahap kognitif. Walau bagaimanapun jenis genre buku yang dibaca juga mampu memberi kesan kepada tahap pemikiran. Hal ini kerana genre buku memberikan ilmu yang berbeza dan kecenderungan ke arah suatu genre buku boleh dikatakan sebagai kecenderungan kepada suatu jenis ilmu. Kajian mengenai minat masyarakat Malaysia terhadap jenis genre dan ilmu boleh diselidik melalui data penerbitan dan harga buku bagi setiap genre buku. Tujuan kajian ini dijalankan adalah untuk menganalisis penerbitan dan purata harga buku di Malaysia dan membandingkannya dengan Jepun. Perbandingan dilakukan melalui strategi pengkategorian genre buku kepada 12 genre buku. Melalui data simulasi Monte Carlo, masyarakat Malaysia didapati meminati genre dan ilmu budaya bahasa, sastera dan sains. Manakala masyarakat Jepun lebih meminati genre dan ilmu sains sosial dan hobi/seni. Persamaan antara kedua-dua masyarakat Malaysia dan Jepun ialah genre sastera, tetapi terdapat kebarangkalian bahawa pengolahan sastera di antara masyarakat Malaysia dan Jepun adalah berbeza. Dapatan kajian ini boleh digunakan untuk mengenal pasti perbezaan dan membuat strategi untuk mengubah amalan pembacaan masyarakat Malaysia ke arah trend pembacaan masyarakat Jepun.
\end{abstract}

Kata kunci: Malaysia, minat membaca, harga buku, genre, simulasi Monte Carlo

\title{
PENGENALAN
}

Buku merupakan suatu sistem rekod yang bertujuan untuk menyimpan dan menyebarkan maklumat dalam bentuk penulisan. Sistem rekod ini boleh wujud di dalam bentuk bercetak ataupun digital. Maklumat ini hanya akan tersimpan sehinggalah seorang pembaca membacanya. Fungsi buku seperti inilah yang telah membawa kepada penghasilan institusi pendidikan seperti perpustakaan dan universiti. Sistem buku ini juga bertanggungjawab membawa tamadun terdahulu ke arah kemajuan. 
Amalan pembacaan buku juga telah dikenal pasti memberi kesan yang positif kepada pembaca. Amalan membaca boleh membantu pembaca meningkatkan kemahiran untuk mengingati maklumat kompleks (Wilson et al. 2013). Amalan membaca juga telah dikenal pasti mampu meningkatkan kemahiran mengingati maklumat dalam suatu tempoh yang lama (Berns et al. 2013).

Sistem penerbitan buku bergantung kepada masyarakat untuk menghasilkan sebuah buku di dalam bahasanya sendiri atau di dalam suatu bahasa yang umum. Unjuran daripada itu, kita boleh melihat perkembangan sastera dan jenis ilmu yang digemari oleh masyarakat dengan melihat data buku yang diterbitkan.

Kajian tentang genre buku di Malaysia adalah amat terhad dan kajian mengenai buku yang sedia ada hanya tertumpu kepada gambaran umum industri buku di Malaysia (Fadli dan Md Sidin 2017; Shalida, Siti Farhana dan Muhammad Yusof 2015), ciri-ciri linguistik dan kebolehbacaan di dalam buku teks pendidikan di sekolah (Kamarulzaman, Ahmad Sabri dan Nik Mohd Rahimi 2017; Aisyah, Maimun dan Nik Mohd Rahimi 2017). Walau bagaimanapun, penyelidik berpendapat kajian mengenai genre buku di Malaysia dapat merungkai lebih lanjut tentang jenis ilmu yang digemari oleh masyarakat di Malaysia. Hal ini kerana genre buku yang berbeza mampu memberi kesan kemahiran berfikir yang berbeza kepada pembaca (Gavaler dan Johnson 2017). Pendapat ini selari dengan analisis wacana kritis iaitu segala jenis kategori teks dan wacana yang dihasilkan oleh masyarakat merupakan analisis penting untuk memahami sesuatu masyarakat tersebut (Fairclough 2001). Maka, kepelbagaian jenis ilmu di dalam konteks ini boleh diterjemahkan melalui kepelbagaian genre buku. Hal ini menunjukkan kecenderungan masyarakat terhadap beberapa genre buku mungkin boleh menjelaskan sedikit sebanyak tentang aspek pemikiran masyarakat tersebut.

Kajian tentang genre buku yang digemari di Malaysia boleh dikaji melalui dua perspektif iaitu harga buku dan data penerbitan buku mengikut genre. Harga buku di pasaran bersifat elastik (Kochkina, Shenkman dan Gordienko 2018; Asai 2017) dan mengikut permintaan dan penawaran oleh masyarakat. Maka, dengan menilai harga buku mengikut genre di pasaran, kita boleh melihat genre buku yang digemari oleh masyarakat di Malaysia.

Selain harga buku, data penerbitan buku mengikut genre untuk suatu tempoh masa juga boleh digunakan untuk mengetahui genre buku yang digemari masyarakat Malaysia. Data penerbitan buku di Malaysia merupakan salah satu data akses terbuka oleh kerajaan Malaysia. Walau bagaimanapun, sekadar menganalisis 
data genre buku oleh masyarakat Malaysia sahaja tidak mencukupi. Kajian ini memerlukan analisis perbandingan data genre buku bahasa asing untuk mengukur perbezaan genre buku yang digemari oleh kedua-dua masyarakat.

Malaysia telah memilih Jepun sebagai model pembangunan pada tahun 1980an. Model ini diterapkan kepada dasar kerajaan dan dinamakan Dasar Pandang ke Timur. Tujuan dasar tersebut adalah untuk mempelajari dan menerap elemen yang menjadi kunci kejayaan pembangunan ekonomi Jepun ke Malaysia. Hasil daripada dasar tersebut, hubungan ekonomi di antara Malaysia dan Jepun menjadi semakin kukuh. Malaysia merupakan salah satu destinasi pelancongan utama dan menjadi salah satu destinasi golongan pesara Jepun menikmati tempoh persaraan (Ono 2017). Malaysia juga telah mengimport bukan sahaja jentera berat, malah amalan sistem pengurusan (seperti sistem pengurusan Kaizen). Walau bagaimanapun, selepas dua dekad dasar tersebut dilakukan, Jepun masih lagi terkenal sebagai salah sebuah negara di Asia yang paling inovatif di dunia (Dutta et al. 2018). Walaupun Malaysia juga telah membangun sejak pelaksanaan dasar tersebut, namun masih terdapat elemen-elemen kejayaan dari Jepun yang boleh diterap untuk memajukan Malaysia.

Selari dengan pengembalian Dasar Pandang ke Timur (The Star Online 2018), penyelidik berpendapat kita boleh membuat perbandingan industri buku di antara Jepun dan Malaysia. Maka, analisis perbandingan genre buku kegemaran masyarakat Jepun dengan Malaysia boleh digunakan untuk melihat perbezaan jenis ilmu yang digemari oleh kedua-dua masyarakat. Hasil kajian ini boleh digunakan untuk merangka strategi atau polisi untuk mengubah aspek pemikiran masyarakat Malaysia ke arah pemikiran yang lebih berinovatif seperti masyarakat Jepun.

Simulasi Monte Carlo merupakan sebuah simulasi yang menggunakan nombor rawak untuk menentukan suatu nilai menggunakan data terdahulu dan pemodelan komputer (Johnson 2013). Simulasi Monte Carlo telah digunakan di dalam kajian undang-undang (Elwart et al. 2006) dan psikologi (Hunt dan Miles 2015). Simulasi ini telah digunakan untuk menentukan simulasi pengurangan jumlah kos yuran guaman yang akan ditanggung oleh Wisconsin sekiranya program geran kepada penyedia perkhidmatan undang-undang dapat diperkembangkan (Elwart et al. 2006). Malah, dapatan daripada kajian penggunaan simulasi Monte Carlo di dalam kajian psikologi merupakan simulasi yang boleh mewakili sifat ketidaktentuan (uncertainty) di dalam penentuan parameter (Hunt dan Miles 2015). Maka, penggunaan simulasi Monte Carlo untuk kajian buku di Malaysia adalah amat bersesuaian. 
Data terbuka oleh agensi kerajaan merupakan salah satu usaha untuk meningkatkan ketelusan kerajaan di dalam penyampaian maklumat kepada orang awam. Walau bagaimanapun, penghasilan data terbuka masih tertakluk kepada usaha agensi-agensi di dalam kerajaan itu sendiri (Yang, Lo dan Shiang 2015). Di Malaysia, kerajaan telah menerbitkan pekeliling am mengenai pelaksanaan data terbuka sektor awam. Pekeliling ini menggariskan panduan untuk agensi-agensi kerajaan di dalam penyediaan dan perkongsian data. Objektif pelaksanaan data terbuka ini adalah untuk menggalakkan pertumbuhan ekonomi negara (Jabatan Perdana Menteri 2015).

Walau bagaimanapun, penggunaan data terbuka oleh kerajaan di dalam kajian yang bertujuan untuk menerokai ketelusan kerajaan atau galakan pertumbuhan ekonomi negara adalah suatu yang sukar. Hal ini kerana penggunaan data terbuka tertakluk kepada usaha dan kreativiti penyelidik itu sendiri (Safarov, Meijer dan Grimmelikhuijsen 2017). Rancangan untuk menyeragamkan aktiviti penggunaan data terbuka kerajaan di dalam kajian di Amerika Syarikat telah dilancarkan melalui medium Massive Open Online Course (MOOC). Apapun, kajian menggunakan data terbuka kerajaan adalah amat digalakkan kerana dapat membantu pengembangan perspektif penggunaan data terbuka untuk kajian pertumbuhan masyarakat sosial.

Kajian ini mempunyai dua objektif iaitu menganalisis penerbitan mengikut genre di antara Jepun dan Malaysia serta mengenal pasti purata harga jualan buku mengikut genre untuk penerbitan di Jepun dan Malaysia. Walaupun data mengenai penerbitan di Malaysia adalah terhad, namun ia masih boleh dicapai dengan pengekstrakan data terbuka dari laman web repositori data terbuka dan laman web kedai buku maya serta penggunaan model simulasi Monte Carlo untuk membuat sesuatu ramalan.

\section{METODOLOGI}

Data penerbitan buku di Jepun diperoleh daripada laporan "An Introduction to Publishing in Japan 2017-2018" yang dihasilkan oleh Japan Book Publishers Association. Laporan ini mengandungi laporan penerbitan mengikut genre, purata harga dan jualan serta laporan tambahan seperti bilangan kedai buku dan perpustakaan di Jepun (International Committee Japan Book Publishers Association 2017). Manakala data penerbitan buku mengikut genre di Malaysia adalah berdasarkan data statistik judul buku-buku yang didaftarkan di bawah Akta Penyerahan Bahan Perpustakaan 1986 (Perpustakaan Negara Malaysia 
2018). Data ini adalah data akses terbuka dan boleh diperoleh di portal data terbuka sektor awam.

\section{Genre Buku}

Pembahagian genre buku di dalam laporan penerbitan Jepun berbeza dengan pembahagian genre buku di dalam data statistik judul buku-buku yang didaftarkan di bawah Akta Penyerahan Bahan Perpustakaan 1986. Oleh yang demikian, pengolahan data statistik judul buku perlu dilakukan untuk tujuan perbandingan. Data statistik Malaysia dibahagikan kepada 26 genre manakala Jepun menyenaraikan 12 genre sahaja (rujuk Jadual 1). Maka, beberapa pembahagian genre daripada data Malaysia perlu digabungkan untuk membuat perbandingan dengan laporan Jepun. Walau bagaimanapun, tidak semua genre digunakan untuk perbandingan kerana kekurangan maklumat. Jadual 1 menunjukkan strategi yang digunakan dalam kajian ini untuk pengkategorian genre buku di antara data penerbitan Malaysia dan laporan penerbitan Jepun. Selain daripada penyenaraian genre buku, data berkaitan dengan purata harga dan jualan buku di Malaysia juga diperlukan untuk perbandingan.

\section{Umum}

Buku bergenre umum mengikut laporan penerbitan Jepun merupakan buku bukan fiksyen yang memberi fakta dalam bentuk senarai maklumat. Buku bergenre umum selalunya tidak mengandungi gaya penceritaan seperti di dalam genre lain. Genre karya umum dan agama daripada data penerbitan buku Malaysia dikategorikan ke dalam genre umum.

\section{Falsafah}

Buku bergenre falsafah mengikut laporan penerbitan Jepun merupakan buku bukan fiksyen yang mengolah isu falsafah dari pelbagai perspektif. Genre falsafah dan psikologi daripada data penerbitan buku Malaysia dikategorikan dalam genre falsafah.

\section{Sejarah/geografi}

Buku bergenre sejarah/geografi mengikut laporan penerbitan Jepun merangkumi buku yang mengolah fakta sejarah dan geografi. Genre sejarah/biografi dan geografi dari data penerbitan Malaysia dikategorikan dalam genre sejarah/geografi. 


\section{Sains sosial}

Buku bergenre sains sosial mengikut laporan penerbitan Jepun termasuk buku yang mengupas isu atau kajian bidang sains sosial kecuali sastera dan bahasa. Genre sosiologi, statistik, sains politik, ekonomi, undang-undang dan pentadbiran awam dikategorikan ke dalam genre sains sosial.

\section{Sains}

Buku bergenre sains mengikut laporan penerbitan Jepun merupakan buku yang mengandungi ilmu sains hayat dan sains fizikal. Genre matematik, sains semulajadi, pertanian, perhutanan, pemburuan, perikanan, sains perubatan dan sains kesihatan awam dari data penerbitan Malaysia dikategorikan sebagai genre sains.

\section{Kejuruteraan}

Buku bergenre kejuruteraan mengikut laporan penerbitan Jepun pula merupakan buku yang mengandungi ilmu kejuruteraan (sivil, elektrik, mekatronik, automobil, senibina dan sains komputer). Genre ketenteraan, teknologi, kejuruteraan, perancangan fizikal, negeri dan bandar serta senibina dikategorikan sebagai genre kejuruteraan.

\section{Industri}

Buku bergenre industri mengikut laporan penerbitan Jepun merangkumi buku di dalam bidang perniagaan dan keusahawanan. Genre perdagangan, komunikasi, pengangkutan, pengurusan pentadbiran dan organisasi dikategorikan sebagai genre industri.

\section{Hobi/seni}

Buku bergenre hobi/seni mengikut laporan penerbitan Jepun ialah buku yang mengandungi ilmu kemahiran hidup yang berfokus ke arah artistik, lakonan, sukan dan hobi. Genre sains rumah tangga, seni plastik dan grafik, seni foto, muzik, seni pertunjukan dan pementasan serta sukan dan permainan dikategorikan sebagai genre hobi/seni. 


\section{Linguistik}

Mengikut laporan penerbitan Jepun, buku bergenre linguistik ialah buku yang mengandungi ilmu tentang tatabahasa dan budaya bahasa. Genre adat resam, sastera dan bahasa daripada data penerbitan Malaysia dikategorikan sebagai genre linguistik.

\section{Sastera}

Buku sastera fiksyen dan bukan fiksyen merupakan buku bergenre sastera mengikut laporan penerbitan Jepun. Genre kesusasteraan daripada data penerbitan Malaysia merupakan kategori yang sesuai untuk genre ini.

\section{Rujukan sekolah}

Berdasarkan laporan penerbitan Jepun, buku genre rujukan sekolah ialah buku untuk kegunaan sekolah serta buku aktiviti dan rujukan untuk subjek yang dipelajari di peringkat sekolah. Genre pendidikan daripada data penerbitan Malaysia dikategorikan sebagai genre rujukan sekolah.

Jadual 1: Strategi pengkategorian genre buku di antara data penerbitan Malaysia dan laporan penerbitan Jepun

\begin{tabular}{ll}
\hline & Genre buku \\
\hline Laporan penerbitan Jepun & Data penerbitan Malaysia \\
\hline Umum & Karya am \\
Falsafsah & Agama \\
Sejarah/geografi & Falsafah/psikologi \\
& Geografi \\
Sains sosial & Sejarah, biografi \\
& Sosialogi, statistik \\
& Sains politik \\
& Ekonomi \\
Sains & Undang-undang, pentadbiran awam, sains sosial \\
& Matematik \\
& Sains semulajadi \\
& Pertanian, perhutanan, pemburuan perikanan \\
& Sains perubatan, sains kesihatan awam \\
\hline
\end{tabular}

(bersambung) 
Jadual 1 (sambungan)

\begin{tabular}{ll}
\hline & Genre buku \\
\hline Laporan penerbitan Jepun & Data penerbitan Malaysia \\
\hline Kejuruteraan & Ketenteraan \\
& Teknologi, kejuruteraan, industri \\
& Perancangan fizikal, perancangan negeri dan \\
& bandar, senibina \\
& Perdagangan, komunikasi, pengangkutan \\
Industri & Pengurusan pentadbiran dan organisasi \\
& Sains rumah tangga \\
Hobi/seni & Seni plastik dan grafik, seni foto \\
& Musik, seni pertunjukan pementasan filem \\
& Sukan dan permainan \\
Linguistik & Adat resam dan sastera \\
& Bahasa \\
Sastera & Kesusasteraan \\
Rujukan sekolah & Pendidikan \\
Kanak-kanak & Tiada \\
\hline
\end{tabular}

Nota: *Tidak digunakan di dalam kajian ini kerana tiada data yang sesuai untuk genre ini.

Pengolahan data terbuka mengenai penerbitan buku Malaysia untuk perbandingan dengan data Jepun ialah suatu perkara yang biasa di dalam analisis menggunakan data terbuka kerajaan. Hal ini kerana setiap kerajaan mempunyai format data terbuka yang tersendiri (Kubler et al. 2018; Nugroho et al. 2015).

\section{Pensampelan Data dan Pengiraan Purata Harga Buku}

Untuk membandingkan data penerbitan di antara Jepun dan Malaysia, maklumat jualan harga buku pada tahun terdahulu perlu diperoleh. Walau bagaimanapun, pengumpulan data purata harga bagi keseluruhan buku penerbitan mengikut genre di Malaysia adalah hampir mustahil kerana tiada data terkumpul pernah diterbitkan oleh mana-mana organisasi di Malaysia (Hafiza 2017). Maka, pensampelan judul buku dan harga perlu diperoleh dengan mengekstrak maklumat di laman web buku dalam talian. Sebagai perbandingan dengan laporan penerbitan Jepun, data penerbitan tersebut perlu diperoleh dari tahun 2015. Laman web arkib internet, Wayback Machine (https://web.archive.org/) digunakan untuk memperoleh pensampelan judul buku dan harga daripada 
tiga laman web kedai buku dalam talian (MPH, Kinokuniya Malaysia dan Popular) pada tahun 2015.

Jadual 2 menunjukkan tiga judul buku di dalam bahasa Malaysia berserta harga pada tahun 2015 disampel secara rawak bagi setiap genre. Selain itu, Jadual 2 turut mengandungi maklumat nama penerbit bagi setiap sampel buku.

Jadual 2: Senarai harga sampel buku dan penerbit

\begin{tabular}{llc}
\hline Genre/sampel & Penerbit & Harga (RM) \\
\hline Umum & & \\
\hline Buku 1 & PTS Millennia Sdn. Bhd. & 19.90 \\
Buku 2 & PTS Millennia Sdn. Bhd. & 29.90 \\
Buku 3 & PTS Islamika Sdn. Bhd. & 18.00 \\
\hline Falsafsah & & \\
\hline Buku 4 & PTS Islamika Sdn. Bhd. & 23.00 \\
Buku 5 & Penerbit Darul Haq & 49.90 \\
Buku 6 & Indie Book Corner & 30.00 \\
\hline Sejarah/geografi & & \\
\hline Buku 7 & Persatuan Sejarah Malaysia & 40.00 \\
Buku 8 & MPH Group Publishing & 59.90 \\
Buku 9 & Medium Publications & 25.00 \\
\hline Sains sosial & & \\
\hline Buku 10 & Penerbit Universiti Malaya & 25.00 \\
Buku 11 & Institut Penyelidikan Kajian Perhutanan Malaysia & 16.80 \\
Buku 12 & (FRIM) & \\
\hline Sains & Penerbit Universiti Malaya & 45.00 \\
\hline Buku 13 & & 20.00 \\
Buku 14 & PTS Islamika Sdn. Bhd. & 30.00 \\
\hline Buku 15 & Institut Terjemahan dan Buku Malaysia Berhad \\
\hline Bukuruteraan 16 & Dewan Bahasa dan Pustaka & \\
Buku 17 & & \\
Buku 18 & Dewan Bahasa dan Pustaka & \\
\hline & & \\
\hline
\end{tabular}


Jadual 2 (sambungan)

\begin{tabular}{llc}
\hline Genre/sampel & Penerbit & Harga (RM) \\
\hline Industri & & \\
\hline Buku 19 & Telaga Biru & 15.00 \\
Buku 20 & AMX Capital Sdn. Bhd. & 39.90 \\
Buku 21 & Inteam Publishing Sdn. Bhd. & 28.00 \\
\hline Hobi/seni & & \\
\hline Buku 22 & Alaf 21 & 21.00 \\
Buku 23 & PTS Millennia & 13.00 \\
Buku 24 & Marshall Cavendish & 16.90 \\
\hline Linguistik & & \\
\hline Buku 25 & Ar-Risalah Product & 18.00 \\
Buku 26 & Dewan Bahasa dan Pustaka & 60.00 \\
Buku 27 & Utusan Publication and Distributors Sdn. Bhd. & 29.00 \\
\hline Sastera & & \\
\hline Buku 28 & PTS Millennia & 25.00 \\
Buku 29 & PTS Millennia & 25.00 \\
Buku 30 & PTS Millennia & 20.00 \\
\hline Rujukan sekolah & & 22.90 \\
\hline Buku 31 & Cerdik Publication & \\
Buku 32 & Sasbadi & \\
Buku 33 & Sasbadi & \\
\hline & & \\
\hline
\end{tabular}

\section{Pensampelan Semula Menggunakan Simulasi Monte Carlo}

Purata daripada pensampelan tiga buku untuk setiap genre akan digunakan untuk pensampelan semula menggunakan pengiraan simulasi. Jenis simulasi yang digunakan ialah simulasi Monte Carlo, sebuah simulasi komputer. Simulasi Monte Carlo merupakan sebuah simulasi yang mengulang pengiraan sampel dengan menggunakan nombor rawak untuk menentukan sifat atau pencirian sesuatu objektif atau aktiviti (Hunt dan Miles 2015). Dalam erti lain, simulasi ini boleh digunakan untuk membuat simulasi pensampelan seberapa banyak yang mungkin dalam cubaan menyerupai pensampelan sebenar. Di dalam konteks kajian ini, simulasi Monte Carlo akan membuat pensampelan dan pengiraan purata harga buku di Malaysia secara simulasi dengan menggunakan maklumat purata harga buku, sisihan piawai, sempadan rendah dan sempadan tinggi daripada data pensampelan buku yang sebenar. Simulasi Monte Carlo untuk 
kajian ini dilakukan dengan menggunakan perisian XLSTAT 2018 (Addinsoft 2018). Nilai maklumat purata untuk setiap genre buku dihasilkan menggunakan fungsi scenario variable, manakala nilai sisihan piawai, sempadan rendah dan tinggi dihasilkan menggunakan fungsi statistik XLSTAT. Simulasi Monte Carlo di dalam perisian XLSTAT menggunakan metod pensampelan latin hypercubes berserta korelasi Spearman.

\section{DAPATAN KAJIAN DAN PERBINCANGAN}

\section{Data Penerbitan Buku di Malaysia}

Setiap buku yang diterbitkan di Malaysia perlu diberikan lima salinan kepada Perpustakaan Negara Malaysia (PNM) seperti yang termaktub di dalam Akta Penyerahan Bahan Perpustakaan 1986. Pada November 2018, PNM telah mengeluarkan data jumlah penerbitan buku dari tahun 2013 sehingga 2017. Walaupun begitu, kategori genre buku PNM telah dikategorikan semula seperti penerangan di dalam bahagian metodologi.

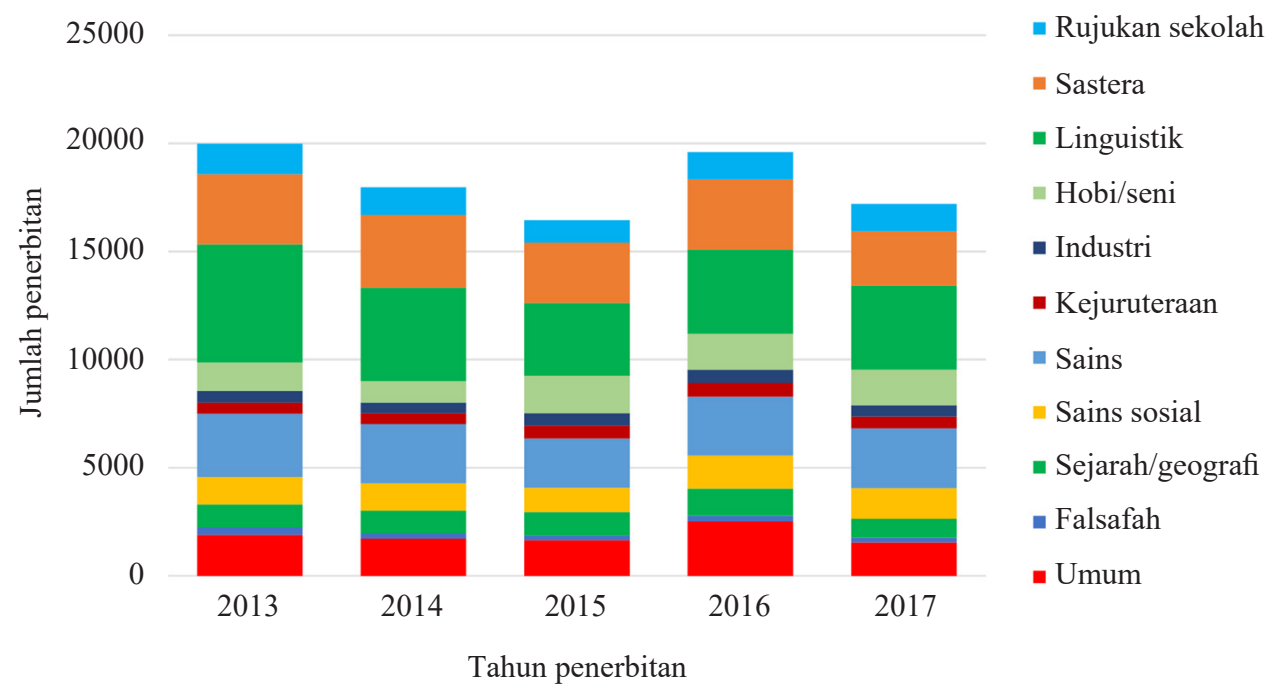

Rajah 1: Jumlah penerbitan mengikut Akta Penyerahan Bahan Perpustakaan 1986 di Malaysia dari tahun 2013-2017.

Rajah 1 menunjukkan jumlah penerbitan mengikut Akta Penyerahan Bahan Perpustakaan 1986 di Malaysia dari tahun 2013 sehingga 2017. Berdasarkan Rajah 1, jumlah penerbitan tertinggi adalah pada tahun 2013 berjumlah 19,987 
buku. Manakala jumlah penerbitan buku terendah adalah pada tahun 2015 dengan jumlah 16,446. Berdasarkan analisis ANOVA terhadap jumlah penerbitan buku di Malaysia, tiada perbezaan signifikan di antara jumlah penerbitan di Malaysia mengikut tahun 2013 sehingga 2017 ( $p>0.05$ ).

Purata peratusan tertinggi penerbitan buku mengikut genre di Malaysia pada tahun 2013 sehingga 2017 ialah genre linguistik (22.86\%) dengan nilai sisihan piawai 3.05. Genre seterusnya ialah sastera $(16.63 \pm 1.486)$, sains $(14.69 \pm 0.940)$, umum (10.21 \pm 1.54$)$, hobi/seni (8.14 \pm 2.08$)$, sains sosial (7.26 \pm 0.75$)$, rujukan sekolah $(6.84 \pm 0.48)$ dan sejarah/geografi $(5.85 \pm 0.64)$. Tiga purata peratusan terendah penerbitan buku mengikut genre di Malaysia pada tahun 2013 sehingga 2017 ialah kejuruteraan (3.08 \pm 0.40$)$, industri (3.02 \pm 0.33$)$ dan falsafah $(1.40 \pm 0.21)$.

\section{Data Penerbitan Jepun}

Laporan penerbitan Jepun untuk isu 2017 sehingga 2018 melaporkan jumlah penerbitan buku pada tahun 2015. Selari dengan itu, data penerbitan buku Malaysia pada tahun 2015 akan digunakan untuk membuat perbandingan. Perbandingan secara langsung di antara kedua-dua negara tidak sesuai dilakukan kerana terdapat perbezaan jumlah yang besar dari segi kuantiti. Maka, penormalan data perlu dilakukan sebelum analisis perbandingan dilakukan.

Skor piawai (standard score) bagi setiap genre daripada data penerbitan keduadua negara dilakukan sebagai langkah penormalan. Skor piawai merupakan pengiraan statistik yang memberi "nilai skor" berdasarkan pengukuran jarak sebuah data daripada minnya. Kelebihan penormalan ini boleh digunakan untuk pasangan data yang berbeza min. Di dalam konteks ini, perbandingan dapat ditentukan apabila data penerbitan dilakukan dalam pengiraan skor piawai.

Rajah 2 menunjukkan perbandingan skor piawai berdasarkan penerbitan mengikut genre di antara Jepun dan Malaysia pada tahun 2015. Antara genre yang sering diterbitkan di Jepun ialah genre hobi/seni, sastera dan sains sosial mengikut urutan menaik (berdasarkan urutan nilai skor piawai). Manakala genre yang sering diterbitkan di Malaysia pula ialah genre sains, sastera dan linguistik mengikut urutan menaik (berdasarkan urutan nilai skor piawai). Genre buku yang mempunyai jumlah penerbitan terendah di Malaysia ialah genre kejuruteraan, industri dan falsafah (berdasarkan urutan menurun nilai skor piawai). Manakala genre industri, linguistik dan umum merupakan antara genre buku yang terendah di Jepun (berdasarkan urutan menurun nilai skor piawai). 


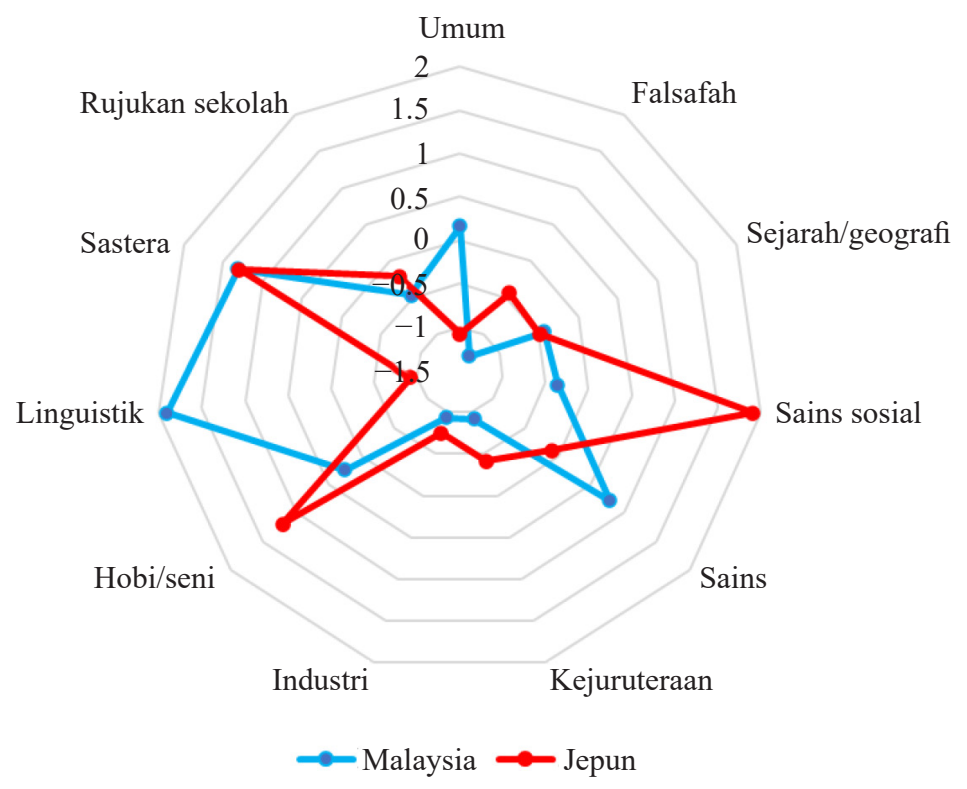

Rajah 2: Perbandingan skor piawai berdasarkan jumlah penerbitan mengikut genre di antara Jepun dan Malaysia pada tahun 2015.

Satu dapatan yang menarik daripada Rajah 2 ialah persamaan genre yang sering diterbitkan oleh kedua-dua negara iaitu genre sastera pada tangga kedua tertinggi. Dapatan ini jelas menunjukkan genre sastera merupakan salah satu genre yang penting untuk kedua-dua negara. Walau bagaimanapun, genre yang mempunyai penerbitan tertinggi di Jepun ialah sains sosial. Manakala genre yang mempunyai penerbitan tertinggi di Malaysia ialah genre linguistik.

\section{Perbezaan dan Perbincangan Data Penerbitan di Jepun dan Malaysia}

Ekstrapolasi daripada dapatan ini ialah masyarakat Malaysia lebih berfokus kepada bahasa, linguistik dan adat resam budaya bahasa. Hal ini dapat dilihat daripada Rajah 1 dan purata peratusan penerbitan buku di Malaysia pada tahun 2013 sehingga 2017. Buku bergenre linguistik dan genre sastera mendominasi jumlah penerbitan buku selama lima tahun berturut-turut.

Kebarangkalian buku bergenre sastera di Malaysia lebih mementingkan kualiti bahasa daripada kepelbagaian genre cerita (stereotaip buku bergenre sastera di Malaysia ialah novel berkisar drama cinta dan isu masalah rumah tangga keluarga yang sering digarap menjadi drama televisyen). Oleh yang demikian, pelbagai buku sastera dan buku mengenai panduan Bahasa Melayu Tinggi 
(BMT) diterbitkan setiap tahun. Walaupun tiada dapatan untuk menyokong penyataan ini, tetapi terdapat banyak artikel dan rencana akhbar yang mementingkan penggunaan BMT di dalam penulisan sastera (Abdullah 2011; Ainon 2006).

Bagi dapatan di Jepun, masyarakatnya lebih berfokus kepada isu sains sosial termasuk isu ekonomi, politik, sosiologi, undang-undang dan pentadbiran awam. Terdapat kemungkinan genre sastera dipengaruhi oleh isu-isu yang dibincangkan di dalam buku bergenre sains sosial. Hal ini kerana isu sosial di Jepun sering dibincangkan di dalam bentuk penulisan sastera sejak zaman dahulu lagi (Shaw 1935). Malah Jepun juga mempunyai dua rakyatnya yang telah memenangi hadiah Nobel bagi kategori sastera (Yasunari Kawabata pada tahun 1968 dan Kenzaburō Ōe pada tahun 1994). Penulisan kedua-dua pemenang Nobel ini juga lebih tertumpu kepada isu sains sosial (penulisan Yasunari Kawabata tertumpu kepada budaya, masyarakat dan pemikiran orang Jepun, manakala penulisan Kenzaburō Ōe tertumpu kepada penulisan bersifat politik yang mengkritik generasi manusia yang bertanggungjawab ke atas Perang Dunia Kedua).

Seterusnya, genre ketiga tertinggi bagi masyarakat Jepun ialah hobi/seni dan sains bagi masyarakat Malaysia. Satu perbincangan yang boleh dibuat bagi dapatan ini ialah buku bergenre sains selalunya berbentuk teoritikal; menerangkan proses alam semula jadi menggunakan konsep abstrak. Manakala genre hobi/ seni selalunya berbentuk praktikal; menerangkan bagaimana untuk melakukan suatu aktiviti dengan panduan penulisan atau bergambar. Walaupun genre sains dan hobi/seni ialah dua genre yang berbeza, perbezaan ini menunjukkan masyarakat Malaysia cenderung kepada ilmu yang bersifat teoretikal manakala masyarakat Jepun lebih cenderung kepada ilmu yang bersifat praktikal.

Berdasarkan genre yang mempunyai penerbitan terendah di Malaysia, kejuruteraan dan industri merupakan genre buku yang mempunyai ilmu praktikal (genre kejuruteraan berfokus pada ilmu kejuruteraan manakala genre industri berfokus pada ilmu pengurusan perniagaan dan wang). Satu dapatan yang menarik dalam kajian ini ialah falsafah merupakan genre yang paling rendah jumlah penerbitannya di Malaysia. Genre ini merupakan ilmu bersifat teoretikal; berfokus kepada asas dan psikologi kemahiran berfikir manusia. Berbalik kepada rumusan masyarakat Malaysia sebelum ini, masyarakat Malaysia masih lagi cenderung kepada ilmu yang bersifat teoretikal, tetapi tidak sampai ke arah ilmu bersifat epistemologi. 
Manakala genre industri, linguistik dan umum merupakan genre yang mempunyai jumlah penerbitan terendah di Jepun. Genre industri merupakan ilmu yang praktikal; berfokus kepada pengurusan perniagaan, keusahawanan dan kewangan peribadi. Antara sebab mengapa genre ini tidak begitu diterbitkan di Jepun mungkin disebabkan oleh budaya Jepun itu sendiri. Hal ini kerana Jepun mempunyai kesedaran yang tinggi tentang penyimpanan dan penyebaran maklumat peribadi atau maklumat sulit organisasi. Konsep kesedaran ini dinamakan Uchi-Soto (Adams, Murata dan Orito 2009). Ada kemungkinan perbincangan mengenai pengurusan perniagaan, keusahawanan dan kewangan peribadi ini kurang dilakukan di dalam bentuk penulisan, tetapi lebih kepada bentuk perbincangan secara lisan.

Genre linguistik merupakan sebuah ilmu yang bersifat teoretikal. Buku bergenre linguistik mungkin tidak begitu diminati kerana masyarakat Jepun mempelajari bahasa Jepun sejak dari sekolah rendah sehinggalah ke sekolah menengah pertengahan hanya untuk mempelajari tulisan Kanji yang asas dalam komunikasi harian (Ishikida 2005). Manakala buku bergenre umum ialah buku yang mempunyai maklumat yang mungkin bersifat teoretikal, atau praktikal atau kedua-duanya. Contoh buku bergenre umum ialah buku panduan pelancongan ke suatu tempat untuk tempoh tertentu seperti panduan bercuti ke Hokkaido pada musim bunga. Buku bergenre sebegini mungkin tidak begitu diminati oleh majoriti masyarakat Jepun kerana ia tidak diperlukan setiap masa dan boleh dirujuk sahaja menggunakan perkhidmatan perpustakaan (Nagata 2007). Berbalik kepada rumusan masyarakat Jepun sebelum ini, masyarakat Jepun cenderung kepada ilmu praktikal yang boleh digunakan dalam hubungan sosial.

\section{Data Harga Buku Mengikut Genre di Malaysia}

Buku merupakan suatu barang "kehendak" (luxury goods) dan bukan suatu barang "keperluan" (Hjorth-Andersen 2000). Penyataan ini adalah benar bagi seorang rakyat dewasa yang tidak perlu memenuhi keperluan buku akademik di peringkat sekolah. Tetapi seorang rakyat dewasa akan membeli buku mengikut kegemarannya. Dari perspektif ini, harga buku akan memainkan peranan di dalam penentuan keputusan seseorang itu.

Seperti yang dinyatakan di bahagian pengenalan, harga buku bersifat elastik. Akan tetapi data kolektif mengenai harga buku mengikut genre di Malaysia tidak wujud. Maka kajian ini membuat pensampelan kecil $(n=3)$ bagi setiap genre dan membuat pensampelan semula menggunakan simulasi Monte Carlo. Simulasi Monte Carlo memerlukan purata harga, sisihan piawai, sempadan rendah dan tinggi untuk melakukan pengiraan simulasi. Pengiraan dilakukan 
sebanyak 1,495 kali. Nilai 1,495 ialah nilai jumlah purata buku yang diterbitkan di Malaysia pada tahun 2015 dan ia digunakan untuk membuat perbandingan yang adil dengan data buku Jepun. Jadual 3 menunjukkan purata harga buku mengikut genre di Malaysia.

Berdasarkan Jadual 3, simulasi harga purata buku tertinggi ialah buku bergenre sejarah/geografi dengan harga RM42.45, diikuti genre linguistik pada harga RM39.00 dan genre falsafah pada harga RM36.45. Simulasi purata harga ini boleh digunakan untuk membuat perbandingan dengan harga buku penerbitan di Jepun menggunakan penormalan skor piawai.

Jadual 3: Hasil pengiraan purata berdasarkan pensampelan semula menggunakan simulasi Monte Carlo

\begin{tabular}{lccccc}
\hline Genre & $\begin{array}{c}\text { Purata harga } \\
\text { (sampel) }\end{array}$ & $\begin{array}{c}\text { Sisihan } \\
\text { piawai }\end{array}$ & $\begin{array}{c}\text { Sempadan } \\
\text { rendah }\end{array}$ & $\begin{array}{c}\text { Sempadan } \\
\text { tinggi }\end{array}$ & $\begin{array}{c}\text { Purata harga } \\
\text { (simulasi) }\end{array}$ \\
\hline Umum & 22.60 & 6.39 & 18.00 & 29.90 & 23.95 \\
Falsafah & 34.30 & 13.96 & 23.00 & 49.90 & 36.45 \\
Sejarah/geografi & 41.63 & 17.51 & 25.00 & 59.90 & 42.45 \\
Sains sosial & 28.93 & 14.51 & 16.80 & 45.00 & 30.90 \\
Sains & 30.00 & 10.00 & 20.00 & 40.00 & 30.00 \\
Kejuruteraan & 17.33 & 8.33 & 8.00 & 24.00 & 16.00 \\
Industri & 27.63 & 12.45 & 15.00 & 39.90 & 27.45 \\
Hobi/seni & 16.97 & 4.00 & 13.00 & 21.00 & 17.00 \\
Linguistik & 35.67 & 21.78 & 18.00 & 60.00 & 39.00 \\
Sastera & 23.33 & 2.89 & 20.00 & 25.00 & 22.50 \\
Rujukan sekolah & 20.57 & 5.86 & 13.90 & 24.90 & 19.30 \\
\hline
\end{tabular}

\section{Perbandingan Skor Piawai Harga Penerbitan Buku di Jepun dan Malaysia}

Laporan penerbitan Jepun mengandungi maklumat harga purata buku mengikut genre. Data tersebut dengan data simulasi purata harga di Malaysia membolehkan analisis perbandingan dilakukan. Berdasarkan data penerbitan buku, purata harga sebuah buku di Malaysia ialah RM27.70 dan $¥ 1,453$ di Jepun. Harga purata ini akan digunakan untuk membuat perbandingan purata harga mengikut genre.

Rajah 3 menunjukkan perbandingan skor piawai harga mengikut genre. Nilai " 0 " di dalam Rajah 3 menunjukkan purata harga buku keseluruhan untuk kedua-dua negara. Nilai skor piawai menunjukkan arah negatif menandakan 
purata harga buku genre tersebut adalah lebih rendah daripada purata harga buku keseluruhan. Nilai skor ke arah positif menandakan purata harga buku genre tersebut adalah lebih tinggi daripada purata harga buku keseluruhan.

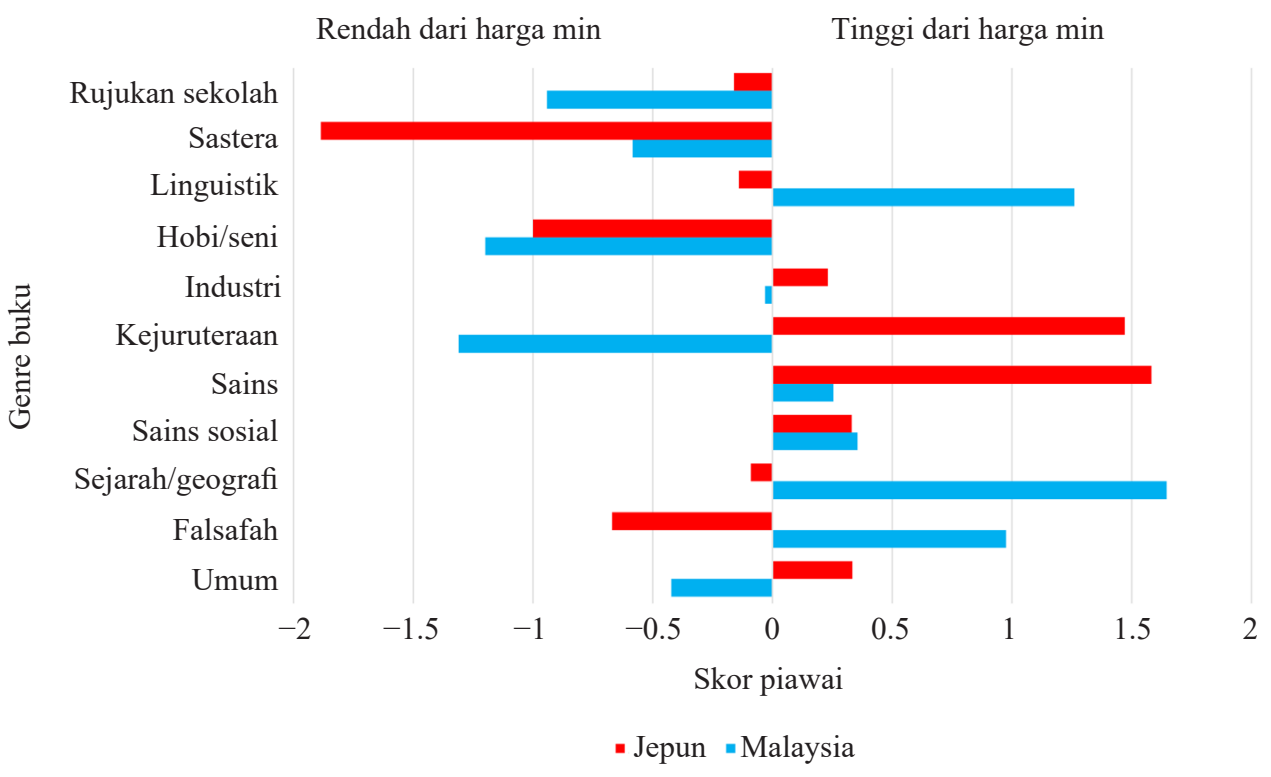

Rajah 3: Perbandingan skor piawai harga penerbitan di Jepun dan di Malaysia pada tahun 2015 .

Berdasarkan Rajah 3, buku bergenre sains dan kejuruteraan di Jepun mempunyai purata harga yang lebih tinggi daripada purata harga buku keseluruhan. Manakala buku bergenre sejarah/geografi dan linguistik di Malaysia mempunyai purata harga yang lebih tinggi daripada purata harga buku keseluruhan. Buku bergenre sastera dan hobi/seni di Jepun merupakan buku yang mempunyai purata harga yang terendah daripada purata harga buku keseluruhan. Manakala buku bergenre kejuruteraan dan hobi/seni di Malaysia mempunyai harga buku terendah daripada purata harga buku keseluruhan.

Hasil kajian mendapati buku bergenre linguistik yang mempunyai jumlah penerbitan tertinggi juga merupakan buku yang mempunyai purata harga buku kedua tertinggi. Jika dilihat dari sudut trend industri buku, harga buku yang mempunyai permintaan yang tertinggi mesti berada berdekatan dengan purata harga buku keseluruhan. Penyataan ini disokong oleh data harga buku Jepun di mana purata harga buku bergenre sains sosial berada berdekatan dengan purata harga buku keseluruhan. 
Hal ini menunjukkan masyarakat Malaysia sanggup berbelanja besar untuk membeli buku kegemaran di mana buku sains dan sastera (yang merupakan buku genre yang mempunyai jumlah penerbitan tertinggi di Malaysia) mempunyai purata harga buku yang berdekatan dengan purata harga buku keseluruhan. Buku agama yang sering dijual di pameran buku di Malaysia (yang dikategorikan sebagai genre umum) juga mempunyai purata harga buku berdekatan dengan purata harga buku keseluruhan. Hal ini menunjukkan Malaysia juga mengikuti trend industri buku.

Buku bergenre sastera yang merupakan titik persamaan di antara Jepun dan Malaysia (dari segi kedudukan jumlah penerbitan tertinggi) mempunyai perbezaan dari konteks harga. Buku bergenre sastera di Malaysia mempunyai purata harga buku yang rendah daripada purata harga buku keseluruhan. Walau bagaimanapun, harganya tidak terlalu jauh daripada purata harga buku keseluruhan. Berbanding dengan Malaysia, buku yang bergenre sama mempunyai purata harga buku terendah di Jepun. Maka, tidak begitu menghairankan apabila buku bergenre sastera mendominasi carta jualan buku pada tahun 2015 (International Committee Japan Book Publishers Association 2017).

Berbalik semula ke perspektif genre sebagai wakil jenis ilmu, masyarakat di Malaysia menggemari ilmu bahasa dan teoretikal. Hal ini boleh dilihat daripada data jumlah penerbitan dan purata harga buku untuk genre tersebut. Malah, kita juga boleh membuat deduksi bahawa masyarakat Malaysia sanggup berbelanja besar untuk memperoleh sumber ilmu tersebut. Berbanding dengan Malaysia, masyarakat Jepun lebih menggemari ilmu sains sosial dan ilmu yang praktikal. Barangkali sifat dahagakan ilmu sebegini yang menyebabkan mereka dikenali sebagai sebuah masyarakat yang inovatif dan berdaya saing. Walau bagaimanapun, penyelidik sendiri berpendapat budaya pembacaan mereka hanyalah salah satu daripada pelbagai acuan untuk menjadi masyarakat inovatif.

Sekiranya hasil kajian ini boleh dijadikan sebagai petunjuk, wujudnya peluang untuk melakukan kejuruteraan sosial (melakukan/menzahirkan suatu perubahan terhadap kehidupan dan sosial masyarakat) masyarakat Malaysia melalui pembacaan. Salah satu caranya ialah dengan meningkatkan penerbitan buku bergenre sains sosial dan hobi/seni. Terdapat kebarangkalian bahawa langkah tersebut dapat mencorak masyarakat Malaysia ke arah masyarakat yang inovatif seperti masyarakat Jepun. Pembuat polisi juga boleh menggunakan hasil kajian ini sebagai panduan untuk merombak strategi budaya membaca dalam kalangan masyarakat di Malaysia. Hal ini boleh dilakukan dengan menyerap genre buku yang mereka yakini akan memberi impak positif (contoh: sains sosial dan hobi/ seni) ke dalam medium pembacaan orang ramai. 
Penulis dan individu yang bercita-cita menjadi penulis juga boleh menggunakan hasil dapatan kajian ini untuk mengorak strategi menulis dan mensasarkan pembaca buku mereka. Sekiranya mahu mengikuti trend industri buku, mereka boleh memilih untuk meneruskan trend yang sedia ada. Hal ini kerana trend penerbitan buku tidak berubah sejak dari tahun 2013 sehingga 2017. Namun, jika mereka ingin terlibat dalam usaha pengubahan pemikiran masyarakat Malaysia, mungkin mereka boleh menulis buku ke arah genre yang kurang diminati atau kombinasi dua genre seperti sastera dan hobi/seni.

\section{PEMBATASAN KAJIAN}

Kajian ini tidaklah sempurna dari segi pelaksanaannya. Salah satu kelemahan kajian ini ialah data bersifat tersirat digunakan untuk membuat penaakulan. Kajian ini menggunakan data simulasi purata harga buku untuk membuat perbincangan dan kesimpulan. Hal ini kerana data harga buku di Malaysia tidak pernah diterbitkan oleh mana-mana pihak berkaitan. Penaakulan yang lebih tepat adalah dengan menggunakan data hasil jualan buku di Malaysia. Tetapi, data hasil jualan buku juga tidak pernah diterbitkan oleh mana-mana pihak. Maka, kajian ini boleh dikatakan sebagai salah satu kajian pertama yang membincangkan tentang analisis purata harga buku mengikut genre dan perbandingannya dengan data negara Jepun.

Kajian ini juga merupakan antara kajian terawal yang menggunakan data terbuka oleh agensi kerajaan Malaysia. Hasil penyelidikan ini diharap dapat menyumbang kepada usaha untuk menerbitkan lebih banyak wacana dan penerbitan seperti yang diseru oleh para cendekiawan di Malaysia (Nur Sabrina 2019). Penyelidik berharap lebih banyak kajian menggunakan data terbuka kerajaan dapat dijalankan pada masa hadapan. Hal ini bertujuan untuk merangsang bukan sahaja pertumbuhan ekonomi tetapi juga pembangunan minda sosial ke arah masyarakat minda kelas pertama.

\section{SARANAN}

Penyelidik mempunyai beberapa saranan untuk kajian lanjutan mengenai penerbitan buku di Malaysia. Saranan yang paling utama adalah untuk mendapatkan data hasil jualan buku di Malaysia. Data tersebut tidak semestinya data hasil jualan buku dari kedai-kedai buku di Malaysia dalam suatu jangka masa panjang. Data hasil jualan buku daripada ekspo jualan buku terkenal juga boleh diguna pakai untuk kajian lanjutan. Selain itu, penyelidik menyarankan 
supaya data penerbitan buku atau hasil jualan buku di Malaysia yang akan datang diklasifikasikan mengikut bahasa penulisan. Hal ini kerana data penerbitan buku mengikut kategori bahasa penulisan (bahasa Malaysia, bahasa Mandarin, bahasa Tamil dan lain-lain) akan membolehkan kajian berkaitan penerbitan buku dan tabiat pembacaan masyarakat yang lebih berfokus dapat dijalankan. Saranan terakhir ialah penambahan genre buku iaitu kanak-kanak untuk data penerbitan buku atau data hasil jualan buku di Malaysia. Data penerbitan buku atau data hasil jualan buku untuk kanak-kanak adalah penting kerana data ini dapat digunakan untuk kajian tabiat pembacaan kanak-kanak dan membolehkan penghasilan saranan polisi yang bersesuaian untuk membentuk tabiat pembacaan kanak-kanak di Malaysia.

\section{KESIMPULAN}

Masyarakat Malaysia meminati genre dan ilmu budaya bahasa, sastera dan sains. Mereka juga didapati sanggup berbelanja lebih untuk membeli buku genre kegemaran mereka. Apabila diamati perbandingan antara masyarakat Malaysia dengan Jepun, terdapat perbezaan genre yang diminati. Masyarakat Jepun lebih meminati genre sains sosial dan hobi/seni. Walau bagaimanapun, kedua-dua masyarakat juga meminati genre sastera berdasarkan posisinya sebagai genre kedua tertinggi penerbitannya di dalam data penerbitan kedua-dua negara. Hasil kajian perbezaan genre buku yang digemari oleh kedua-dua masyarakat ini boleh digunakan untuk merombak pemikiran masyarakat melalui pembacaan. Terdapat kemungkinan sekiranya genre kegemaran pembacaan masyarakat Malaysia berubah mengikut genre kegemaran pembacaan masyarakat Jepun, ia akan membantu masyarakat Malaysia menjadi lebih produktif dan inovatif.

\section{RUJUKAN}

Abdullah Hassan. 2011. Sukatan pelajaran Bahasa Melayu 2002 (pindaan): Antara penggabunganjalinan kemahiran berbahasa dan tatabahasa dengan penyerapan kemahiran bernilai tambah. In Pancadimensi pengajaran dan pembelajaran bahasa: Trend dan amalan, eds. A. Pandian, Murshidi Harun@Zakaria, H.T. Tan, Siti Noraini Jupri and N. Ali, 3-24. Pulau Pinang: Penerbit Universiti Sains Malaysia.

Adams, A.A., K. Murata and Y. Orito. 2009. The Japanese sense of information privacy. AI \& SOCIETY 24(4): 327-341. https://doi.org/10.1007/s00146-009-0228-z

Addinsoft. 2018. XLSTAT 2018: Data analysis and statistical solution for Microsoft Excel. Paris, France: Addinsoft. https://www.xlstat.com (accessed 16 November 2018). 
Ainon Mohd. 2006. Menulis dan menerbitkan buku sastera remaja tinggi (SRT) adalah pelaburan jangka masa panjang. http://universitipts.com/index.php/site/ comments/menulis_dan_menerbitkan_buku_sastera_remaja_tinggi_srt_adalah_ pelaburan_jan/ (accesse- 1 March 2019).

Aisyah Sjahrony, Maimun Aqsha Lubis and Nik Mohd Rahimi Nik Yusoff. 2017. Kepentingan kebolehbacaan buku teks dalam dunia pendidikan. ASEAN Comparative Education Research Journal on Islam and Civilization (ACER-J) 1(1): 25-40.

Asai, S. 2017. Demand analysis of novels released as books and pocket-sized paperbacks in Japan. Publishing Research Quarterly 33(2): 147-159. https://doi.org/10.1007/s12109-017-9502-y

Berns, G.S., K. Blaine, M.J. Prietula and B.E. Pye. 2013. Short- and long-term effects of a novel on connectivity in the brain. Brain Connectivity 3(6): 590-600. https://doi.org/10.1089/brain.2013.0166

Dutta, S., B. Lanvin and S. Wunsch-Vincent, ed. 2018. The global innovation index 2018: Energizing the world with innovation. 11th ed. New York, France and Switzerland: Cornell University, INSEAD and the World Intellectual Property Organization. https://www.wipo.int/publications/en/details.jsp?id $=4330$ (accessed 20 November 2018).

Elwart, L., N. Emerson, C. Enders, D. Fumia and K. Murphy. 2006. Increasing access to restraining orders for low-income victims of domestic violence: A cost-benefit analysis of the proposed domestic abuse grant program. https://legalaidresearch .org/2020/01/28/increasing-access-to-restraining-orders-for-low-income-victims -of-domestic-violence-a-cost-benefit-analysis-of-the-proposed-domestic -abuse-grant-program/ (accessed 7 March 2019).

Fadli Abdullah and Md Sidin Ahmad Ishak. 2017. Kesan perkembangan teknologi terhadap industri penerbitan buku di Malaysia. Jurnal Pengajian Media Malaysia 18(2): 71-86.

Fairclough, N. 2001. Critical discourse analysis as a method in social scientific research. In Methods of critical discourse analysis, eds. R. Wodak and M. Meyer, 121-138. London: SAGE Publications.

Gascó-Hernández, M., E.G. Martin, L. Reggi, S. Pyo and L.F. Luna-Reyes. 2018. Promoting the use of open government data: Cases of training and engagement. Government Information Quarterly 35(2): 233-242. https://doi.org/10.1016/ j.giq.2018.01.003

Gavaler, C. and D. Johnson. 2017. The genre effect: A science fiction (vs. realism) manipulation decreases inference effort, reading comprehension, and perceptions of literary merit. Scientific Study of Literature 7(1): 79-108. https://doi.org/ 10.1075/ssol.7.1.04gav

Hafizah Iszahanid. 2017. Senarai buku "best seller" Malaysia tiada rujukan data. Berita Harian. 30 November. https://www.bharian.com.my/rencana/sastera/ 2017/11/357100/senarai-buku-best-seller-malaysia-tiada-rujukan-data (accessed 24 November 2018).

Hjorth-Andersen, C. 2000. A model of the Danish book market. Journal of Cultural Economics 24(1): 27-43. 
Hunt, P. and J.N.V. Miles. 2015. An introduction to Monte Carlo simulations in criminal psychology: Applications in evaluating biased estimators for recidivism. Journal of Criminal Psychology 5(2): 149-156. https://doi.org/10.1108/jcp-02 $-2015-0008$

International Committee Japan Book Publishers Association. 2017. An introduction to publishing in Japan 2017-2018. https://web.archive.org/web/20190203154323/ https://www.jbpa.or.jp/en/pdf/pdf01.pdf (accessed 24 November 2018).

Ishikida, M.Y. 2005. Secondary education. In Japanese education in the 21st century, 72-110. New York: iUniverse.

Jabatan Perdana Menteri. 2015. Pelaksanaan data terbuka sektor awam (Pekeliling Am Bil. 1 Tahun 2015). Putrajaya: Jabatan Perdana Menteri.

Johnson, P.E. 2013. Monte Carlo analysis in academic research. In The Oxford handbook of quantitative methods in psychology (Vol. 1), ed. T.D. Little, 1-48. Oxford: Oxford University Press.

Kamarulzaman Abdul Ghani, Ahmad Sabri Noh and Nik Mohd Rahimi Nik Yusuff. 2017. Ciri-ciri linguistik dalam buku teks berbahasa Arab dan hubungannya dengan tahap kebolehbacaan teks di Malaysia. GEMA Online ${ }^{\circledR}$ Journal of Language Studies 17(3): 152-166. https://doi.org/10.17576/gema-2017-1703-10

Kochkina, N.A., E.A. Shenkman and A.S. Gordienko. 2018. The elasticity of demand for books: The research of the north-Western federal district book market. Вестник СПбГУ. Менеджмент 17(1): 99-117. https://doi.org/10.21638/ $11701 /$ spbu08.2018.105

Kubler, S., J. Robert, S. Neumaier, J. Umbrich and Y. Le Traon. 2018. Comparison of metadata quality in open data portals using the analytic hierarchy process. Government Information Quarterly 35(1): 13-29. https://doi.org/10.1016/j.giq .2017 .11 .003

Nagata, H. 2007. Public libraries in Japan: Triggers for the renovation of library service models. Paper presented at the Congreso Internacional, La Biblioteca Publica, Medellin Colombia. 20-23 November.

Nugroho, R.P., A. Zuiderwijk, M. Janssen and M. de Jong. 2015. A comparison of national open data policies: Lessons learned. Transforming government: People, process and policy 9(3): 286-308. https://doi.org/10.1108/tg-03-2014-0008

Nur Sabrina Suhaimi. 2019. Malaysia perlu banyakkan wacana, terbit buku ilmiah. Berita Harian. 4 March. https://www.bharian.com.my/rencana/sastera/2019/03/537217/ malaysia-perlu-banyakkan-wacana-terbit-buku-ilmiah (accessed 7 March 2019).

Ono, M. 2017. Fleeing from constraints: Japanese retirement migrants in Malaysia In Escaping Japan: Reflections on estrangement and exile in the twenty-first century, eds. B. Guarné and P. Hansen, 217-236. UK: Routledge.

Perpustakaan Negara Malaysia. 2018. Statistik judul buku-buku yang didaftarkan di bawah akta penyerahan bahan perpustakaan 1986. http://www.data.gov.my/ data/ms_MY/dataset/statistik-judul-buku-buku-yang-didaftarkan-di-bawah-aktapenyerahan-bahan-perpustakaan-1986 (accessed 17 November 2018).

Safarov, I., A. Meijer and S. Grimmelikhuijsen. 2017. Utilization of open government data: A systematic literature review of types, conditions, effects and users. Information Polity 22(1): 1-24. https://doi.org/10.3233/IP-160012 
Shalida Mohd Rosnan, Siti Farhana Zakaria and Muhammad Yusof Masod. 2015. An overview of the book printing and publishing industry in Malaysia, In International Colloquium of Art and Design Education Research (i-CADER 2014), eds. Oskar Hasdinor Hassan, Shahriman Zainal Abidin, Rafeah Legino and Rusmadiah Anwar, 551-557. Singapore: Springer. https://doi.org/10.1007/ 978-981-287-332-3_56

Shaw, G.W. 1935. Contemporary Japanese literature: A foreigner's view. Pacific Affairs 8(3): 292-301. https://doi.org/10.2307/2751472

The Star Online. 2018. Malaysia and Japan to revive Look East policy. 12 June. https://www.thestar.com.my/business/business-news/2018/06/12/malaysia-and -japan-to-revive-look-east-policy/ (accessed 20 November 2018).

Wilson, R.S., P.A. Boyle, L. Yu, L.L. Barnes, J.A. Schneider and D.A. Bennett. 2013. Lifespan cognitive activity, neuropathologic burden, and cognitive aging. Neurology 81(4): 314-321. https://doi.org/10.1212/WNL.0b013e31829c5e8a

Yang, T.-M., J. Lo and J. Shiang. 2015. To open or not to open? Determinants of open government data. Journal of Information Science 41(5): 596-612. https://doi.org/10.1177/0165551515586715 